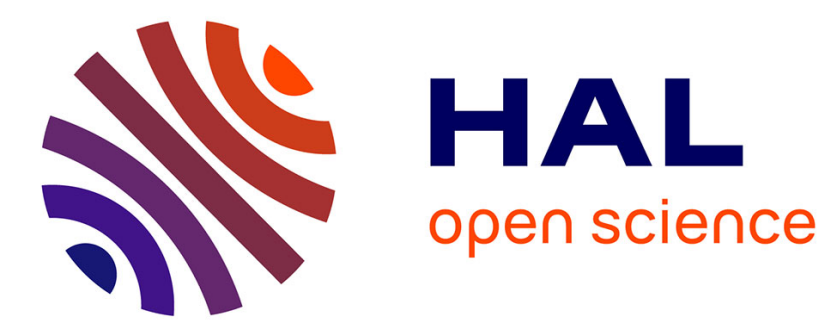

\title{
Rebalancing society: Learning from the experience of Latin American progressive leaders
}

\author{
Guilherme Azevedo, Jorge Carneiro, Carlos Rodriguez, Maria Alejandra \\ Gonzalez-Perez
}

\section{> To cite this version:}

Guilherme Azevedo, Jorge Carneiro, Carlos Rodriguez, Maria Alejandra Gonzalez-Perez. Rebalancing society: Learning from the experience of Latin American progressive leaders. Journal of Business Research, 2020, 119, pp.511-521. 10.1016/j.jbusres.2020.08.007 . hal-03115436

\author{
HAL Id: hal-03115436 \\ https://hal.science/hal-03115436
}

Submitted on 7 May 2021

HAL is a multi-disciplinary open access archive for the deposit and dissemination of scientific research documents, whether they are published or not. The documents may come from teaching and research institutions in France or abroad, or from public or private research centers.
L'archive ouverte pluridisciplinaire HAL, est destinée au dépôt et à la diffusion de documents scientifiques de niveau recherche, publiés ou non, émanant des établissements d'enseignement et de recherche français ou étrangers, des laboratoires publics ou privés. 


\title{
REBALANCING SOCIETY: \\ LEARNING FROM THE EXPERIENCE OF LATIN AMERICAN PROGRESSIVE LEADERS
}

\author{
Guilherme Azevedo ${ }^{\mathrm{a}}$, Jorge Carneiro ${ }^{\mathrm{b}}$, Carlos Rodriguez ${ }^{\mathrm{c}}$, Maria Alejandra Gonzalez-Perez ${ }^{\mathrm{d}}$ \\ a Audencia Business School, France, (gazevedo@audencia.com) \\ ${ }^{\mathrm{b}}$ FGV EAESP, Brazil, (jorge.carneiro@fgv.br)

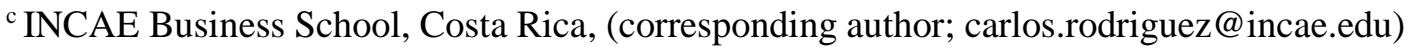 \\ d Universidad EAFIT, Colombia, (mgonza40@eafit.edu.co)
}

\begin{abstract}
This study reports on lessons learned from the experience of 25 progressive leaders in Brazil, Colombia, Costa Rica, and Uruguay who are engaged in contributing to advance their societies towards a better future. In particular, we examined if the solution to complex societal problems could profit from Mintzberg (2015) 'rebalancing society' proposition. The study unveils a strong agreement among them about the most crucial problems faced in the region and, to an extent, how to solve them. Moreover, although these leaders tend to agree with the 'rebalancing society' underlying principles, the study also indicates that the proposition does not fully account either for the context of low-quality institutions that is typical of Latin America or for the need for a more profound shift of mentality in the region.
\end{abstract}

Keywords: rebalancing society, Latin America, progressive leaders, complex problems

\section{$\underline{\text { Introduction }}$}

This study builds upon the rebalancing society proposition forwarded by Henry Mintzberg (2015), which posits that, in order to address complex societal problems, a society needs to build a balance among the public sector (governments), the private sector (businesses), and the plural sector (also referred to as civil society, third sector, not-for-profits, or social sector). Latin America, as a region historically plagued by crises (social, economic, political, and environmental) and still struggling 
to find its socioeconomic development routes, provides a suitable case to assess the applicability of Mintzberg (2015) proposition. We thus address the following research question: does the rebalancing society proposition find support in the experience of those who are actively engaged in addressing complex societal problems in Latin America?

To answer this question, we interviewed 25 individuals in Brazil, Colombia, Costa Rica, and Uruguay, who are considered progressive leaders because - as public officers, businesspeople, or activist members of civil society - they promote constructive practices to advance their societies towards a better future. Our results indicate that these progressive leaders tend to agree about the most crucial problems faced in the region and, to an extent, how to solve them. The analysis of the interviews also leads us to posit that, although the interviewees tend to agree with the principles underlying the rebalancing society proposition, the perspectives they voiced indicate that the proposition does not fully account either for the context of low-quality institutions that is typical of Latin America or for the need for a more profound shift of mentality in the region.

This paper also opens the JBR's special issue on Latin America, composed of some of the best papers presented at the SMLA 2019 conference (http://x.incae.edu/smla2019/), held at FGV in São Paulo, in February 2019, whose theme was "How can Latin American firms contribute to a more rebalanced society." Carlos Rodríguez and Jorge Carneiro served as co-chairs of the conference and guest editors of this special issue. The eight papers selected (after four rounds of double- blind review) cover firm-level determinants of profitability, the in- stitutional environment of the region, and competitive strategies.

\section{Theoretical ground: the rebalancing society proposition}

The rebalancing society proposition saw the light of the day in 2014 when Mintzberg released the pamphlet Rebalancing society: radical renewal beyond left, right and center, later published as a book (and as a free electronic book) (Mintzberg, 2015). The seminal arguments presented in the book can be traced back to 1991, when Mintzberg began to formulate responses to the conclusion 
that capitalism had triumphed (Azevedo \& Gates, 2019) and that we "live in a world where everybody follows the same rules and understands the same language of profit-making" (Milanovic, 2019, p. 3). In its final formulation, the proposition criticizes the adoption of dichotomous views such as capitalism or socialism, right or left, and markets or governments, which Mintzberg deems insufficient to understand why many societies are out of balance. Instead, he proposes a formulation that eventually leads to the argument that achieving balance requires overcoming these dichotomous views and conceiving societies as composed by three complementary and mutually dependent sectors:

The central theme of the book is that a balanced society finds a certain balance across three sectors, not two. My argument is that when you only recognize two sectors, which is what we do - public and private, nationalization and privatization, Adam Smith and Karl Marx, capitalism and communism, and so on and so forth-you either swing back and forth, which many countries do - or you are paralyzed in the middle. It's unhealthy. You can't balance a stool on two legs, but if you add a third leg-and I call it the plural sector-balance is more probable. People call it civil society, not-for-profit, NGOs, social sector, or community sector. The trouble is that it has got so many labels, and I wanted a label that would see it taking its place alongside the other two. So, public, private, plural sound like they go together. Also, it is plural because it is much more eclectic, much more varied than the other two sectors. (Mintzberg, quoted in Azevedo \& Gates, 2019, p. 181)

The plural sector is hence characterized by its diversity, comprising a myriad of organizations of various forms and sizes that cannot be considered either as government or as businesses, such as NGOs, unions, cooperatives, churches, foundations, many of the most prestigious universities and hospitals, and all sorts of social movements led by community groups (Mintzberg, 2015).

Mintzberg's (2015) characterization of the plural sector differs therefore from the notion of societas civilis postulated by Rousseau (1792) in his Social Contract, in which civil society is conceived as a free and equal relationship between the state and the individual (Matravers, 1998). Until the $19^{\text {th }}$ century, the separation of state and civil society was unclear, in the same way that there was no distinction between civil society and the market (Keane, 2005). This early notion of civil society implies that all non-state actors (including businesses as socio-economic actors) and their social function perform soft regulation and moral authority, which transcends the role of states as enforcers (Castells, 2008; Gellner, 1995; Gonzalez-Perez, 2013). The conceptualization of civil society can be seen as a reflection of historical circumstances and a manifestation of public 
responses to forms of inequality, associated either with the market and private sphere (i.e., Ferguson, Smith, and Marx), or with politics and the private sphere but not the state (i.e., Hegel and Gramsci). The idea of civil society opened a space for non-traditional political actors to actively engage and participate in the political process of societal change (Gonzalez-Perez, 2013); thus, the definition of civil society reflects the diversity of the discourses and actors. "On the one hand, civil society consists of the social and institutions that structure and facilitate the governance of democratic forces that lead towards the meeting public needs. On the other hand, civil society represents autonomous forms of resistances outside of the state sphere and the marketplace, at the local and the global level” (Gonzalez-Perez, 2013, p. 56).

Therefore, even if adopting an unusual perspective to refer to what others have called the civil society (or third sector, social sector...), Mintzberg's (2015) view built upon previous perspectives, and the rebalancing society proposition can be boiled down to the argument that we need to readjust our societies because the solution of complex societal problems depends on a balanced interaction among the public, private, and plural sectors (Mintzberg, 2015; Mintzberg \& Laasch, 2020).

\section{Method}

To learn about the roots and manifestations of societal imbalance and to gain awareness about potential ways around it, we chose to examine Latin America, a region historically marked by high levels of instability, with several of its nations often oscillating between socialist and capitalist dominant ideologies. The region thus seems to depict the very seminal dilemma of oscillation between government power and market power (or public and private) that gave origin to the rebalancing society proposition. Moreover, the difficulties many Latin American nations encounter to fulfil the socio-economic aspirations of their populations also create a fertile ground for the emergence of plural sector initiatives. These traits of the region suggest that Latin America provides suitable empirical ground to examine the rebalancing society proposition. 
We interviewed 25 individuals (Table 1) who are active in the three sectors defined in Mintzberg's (2015) proposition and who are engaged in the solution of societal problems. We consider these individuals as progressive leaders because they are public officers and policymakers, devoted businesspersons, and vigorous representatives of civil society (many of whom have occupied different positions in these three spheres) who are recognized as concerned with the future of their societies and who are actively engaged in the promotion of constructive practices in their own sectors and often across sectors. Due to practical constraints, we decided to concentrate our data collection in four Latin American countries: Brazil, Colombia, Costa Rica, and Uruguay. These should provide a valid representation of central aspects of the Latin America reality with Brazil and Colombia exemplifying the case of large-population countries that have endured extreme lack of stability over the last 50 years and Costa Rica and Uruguay representing smaller nations that are notably stable in the Latin American context. We present some national indicators in Table 2 for the sake of better contextualizing and contrasting these four countries.

--- Table 1 ---

--- Table 2 ---

Since this study aimed at learning from the experience of Latin American progressive leaders, we opted for purposeful intensity sampling instead of random sampling, thus providing us with "information-rich cases that manifest the phenomenon intensely, but not extremely" (Patton, 2002, p. 243). Given their rich experience in multiple sectors and their intense engagement in the transformation of society, they can provide reasoned scrutiny that can serve as the basis for systematic reflection and action. Indeed, the content of the interviews convinced us that the assortment of perspectives - although far from homogeneous - belongs to original thinkers who reflect on crucial issues at local and global levels and who are committed to build solutions they consider desirable and suitable.

We conducted the interviews in a semi-structured mode, posing a sequence of eight guiding questions to the interviewees, who were afforded considerable leeway to discuss their own topics 
of interest. The interviews took place between December 2019 and February 2020, lasted for an average of 70 minutes, and were conducted in the interviewee's first language by an interviewer of the same mother tongue.

In the first part of the interview the interviewees presented and discussed their perspectives and experiences on the societal problems they considered the most crucial and on ways of addressing them. We encouraged the interviewees to describe specific cases and to comment on the roles of the private and the public sectors as well as of the civil society. We then briefly presented the central aspects of the rebalancing society proposition and invited the interviewees to express their perspectives on the proposition. The final question of the interview was about possible lessons that Latin America could teach or learn from other parts of the world.

All interviews were transcribed verbatim in their original languages (all co-authors read both Portuguese and Spanish) and then coded using qualitative analysis software (Atlas.ti). We adopted an inductive approach that began with an in vivo coding of the interviews (Bernard \& Ryan, 1998) that preserved endogenous language, therefore reducing the possibility of the research team introducing biases to the primary data. We treated the data in its original languages; the quotations we present in the article are our translations. The 25 interviews generated 211 codes containing 746 quotations. We later recombined these primary data in second-order categories (i.e., "using researcher-centric concepts, themes, and dimensions" [Gioia et al., 2013, p. 18]) that allowed for the emergence of hypothetical relations among codes and groups of codes. The presented findings are therefore the result of a combination of first-order analysis (i.e., "an analysis using informantcentric terms and codes" [Gioia et al., 2013, p. 18]) and inductive analysis (i.e., the disclosure of "undiscovered patterns and emergent understandings" [Patton, 2002, p 454]).

\section{Findings}

The study shows that the progressive leaders we interviewed tend to agree vis-à-vis the most crucial problems in the region. They also tend to perceive these problems as interconnected and 
requiring collaboration. The study indicates that, by sharing a common history, countries in the region tend to face similar issues despite the diversity of national contexts. Although cautious when asked if Latin America has lessons to teach to other regions, the interviewees tend to share a vision for the region and, more importantly, to generally agree on how to address Latin America's most crucial problems.

\section{There is convergence in terms of the most crucial problems}

The interviewees provide a comprehensive perspective on extant societal problems in Latin America, and their statements generated 63 specific categories of problems. Despite such apparent diversity of points of view, there is remarkable convergence in terms of which problems they consider as the most crucial, with three being the most salient: inequality, environmental degradation, and dysfunctional political systems. We comment briefly on each.

Inequality emerges as the main concern of Latin American progressive leaders. They often characterize inequality in terms of economic disparity but also in terms of concentration of power. It is striking that the codes referring to poverty and unattended vulnerable people are mentioned only three times, whereas the codes referring to inequality and power concentration are mentioned 62 times. To offer some contextual information, Table 3 presents some indicators related to instances of inequality in the region.

--- Table 3 ---

Clearly, the progressive leaders are much more concerned with the distribution than the creation of wealth:

Inequality is the number one problem, an excessive concentration of powers in companies and the state, and in the Church. (CO-04)

We are living in a moment of so much wealth and [at the same time] so much deprivation for so many millions of people, which is such an injustice! (BR-06)

A country's strength is not the rich becoming richer, but the poor becoming richer. There are studies that show that violence is not linked to poverty, but to inequality. (BR-03)

Inequality can also be made worse by unfair development modes and ways of doing business: 
For a guy to be a billionaire, usually someone paid that bill. It was often the environment or... [A given food delivery company] is a unicorn worth a billion dollars. Cool, but there is a guy who works 12 hours a day, 7 days a week, sacrificing his life to earn 200 bucks a month. Is that fair? (BR-03)

Even in Uruguay, where poverty is not a critical issue and where there is an "almost complete absence of extreme poverty" (World Bank, 2019), inequality appears as a crucial problem:

Today, there is a big difference between a family that has money and another that does not. They are two children who were born on the same day, but in context they are so different; their lives are already completely predetermined. (UY-02)

Similarly, in Costa Rica, which used to be a rather equal country, inequality has now become a problem:

Where I grew up in Costa Rica, where the rich, the poor, and the middle class went to the same school, the same hospital, we lived in the same neighborhood, we entertained ourselves in the same park and when we were adults in the same canteen. Today, the only thing we have in common is that we cheer for the same football team. (CR-01)

Their concern about inequality is manifested in various forms, including disparity in family income levels and ownership of assets and goods, unfair relations between capital and labor, and, more broadly, unequal access to opportunities and basic services, such as education, health care, and public safety. They present inequality as multifaceted:

[...] issue of income and jobs, education, and also access to technology, there is inequality in these three fields. (CR-03)

In Brazil, [...] we have a housing deficit and the most popular strata have an even greater difficulty." (BR-02)

The middle class has been declining [but] the most worrying is how the lower class has increased" (CR-05)

Despite being evident from the statistics, inequality often escapes the attention of the well-off, who are more concerned with the growth of GDP (gross domestic product) rather than its distribution:

There is little communication between different neighborhoods [in the same city] [so that] they [the well-off] never come to know the weaknesses of other people, of other citizens of the same city who actually need some opportunity. [It has to do with lack of] social integration. (UY-02)

It seems to me that the general problem in the world today is the growing inequality. And inequality, not only in economic terms but in ideological terms, in terms of the paradigm of how the world is, that things seem to be ever more black and white or in terms of extremes (UY-03).

Such state of affairs is critical, since part of the solution to inequality would be the cooperation between the public and the private sector: 
[Public] policy [should] work precisely in the sense of joining forces [between the state and companies] to end inequality. (CO-07)

Environmental degradation also emerges as a major concern among the interviewees.

Degradation is typically expressed in terms of deforestation, biodiversity loss, pollution, climate change, and depletion of natural resources (Table 4 offers some relevant indicators of the four countries).

--- Table 4 ---

The interviewees mention their concern with local dynamics, such as river pollution, precarious urbanization, and inappropriate individual behavior, as well as global issues, in particular global warming and the carbon footprint of global value chains and attendant pollution.

Climate emergency is for me the biggest challenge that humanity has ever faced. (BR-04)

The main problem we face is the one of the environment, climate change, environmental pollution, and species going extinct. This is both a global and local problem. (CO-02)

We should be addressing the issue of climate as a crisis, as an emergency. (CO-03)

The progressive leaders we interviewed are concerned about environmental degradation and particularly unsatisfied with the stance that both the public and the private sectors take on this issue. Concerning the government, they question the speed of reaction and the inability to establish modifications to the system in order to foster effective action:

The only way to get the market to act is to get the government to step in and change the rules of the game. But the government is not functioning. If we look at the predominant way of government, democracy can almost never solve the problem until it is way too late. Its capacity to look down the road and anticipate a problem is limited. (CO-06)

Other regions can learn from Latin America vis-à-vis how elected politicians can have serious environmental impacts; that is, Latin America clearly demonstrates how a president can damage an ecosystem through ignorance alone. (CO-04)

With regard to the private sector, the criticism is more on how value chains are managed and how governments fail to implement better environmental protection practices:

We need to re-think global value chains. The carbon footprint of international transportation is vast. $(\mathrm{CO}-01)$

The obsolete business models fail to consider the sustainability of the value chain. (CO-02) 
We need legislation with implementation and compliance because we live in a society with entrenched corrupt practices. (CR-04)

Governments have been focused only on pursuing, penalizing, and fining those who pollute and generate emissions; policies or incentives for moving towards an environmentally friendly economy are lacking. (CO-08)

Environmental degradation and climate change due to human intervention is deemed as the most pressing issue to be addressed, one that risks the very survival of the human race. However, they also acknowledge that in the region and for significant parts of the society, these issues are is not perceived as of the highest urgency, particularly in the context of the more pressing economic demands of the poorest sectors of society.

In Latin America, we're always going to give priority to social issues. If a large foreign multinational wants to invest in our countries, would you give priority to 40,000 new jobs, or to the environment? We need to move towards conciliating both. (UY-01)

Interestingly, the aspirations to sustainability also trigger reflections about the challenges to reduce inequality:

It is difficult even for the sake of sustainability to think of a world in which everyone has the same things and equal access to everything because there is no planetary capacity for this. This means the haves reducing their share, which is a conundrum. Nobody wants to give up what they have. (BR-06)

The dysfunctionality of political systems is also considered a crucial problem in the region. This factor is typically related to dysfunctional democracies and government models and is described as encompassing, among other aspects, corruption, unfair elections, ideological manipulation, populism, political polarization, and public officers using the state in a self-serving manner. Table 5 presents some indicators that can be related to the dysfunctionality of political systems in the four selected countries.

The progressive leaders we interviewed are in general pessimistic about the political systems and their ability to provide solutions to challenges emerging regionally. Some express concerns about the representatives of the public bodies, as the state seems to have been coopted by politicians and their network: 
The state [seems] not to have the objective of serving the population but in the first instance serving them [the politicians]; their capacity for organization and mobilization has allowed this, and this is an insult to the rest of the citizenry. (CR-01)

But others center on structural deficiencies of the democratic system. They are particularly concerned about the ability of the democratic system to deal with emerging challenges in the region. On one side, they point to the limited ability of Latin American democratic systems to prepare for the future as they seek to cope with multiple demands to solve immediate pressures.

On the other, they describe barriers to increase productivity in the public sector, such as limitations to incorporate metrics to evaluate the performance of public servants:

"We need to face honestly that our democratic governments have serious limitations. Democracy can almost never solve the problem until it is way too late. Government capability to look down the road and anticipate a problem is very limited. (CR-06)"

We don't have the results that correspond to the large budgets invested in the public education. Technically the problem has an obvious solution: you have to tie public servants' performance to rewards; but politically it is a very difficult issue to solve. (CR-03)

Combined, these alleged dysfunctionalities tend to lead to social injustice and to the erosion of trust in the governments, which are perceived as detached from the people:

The state is both weak and impotent; plus, there is a lack of proximity between the state and citizens. We need a reform in the structure of the state to close the gap. (CO-07)

Ultimately, these can lead to both preoccupation with the state of Latin American democracies and questioning as to whether democracies can solve the most crucial problems of the region:

Democracy is in serious danger. We are experiencing a great threat to individual freedoms and economics. (CO-07)

Democracy was the least worse of all systems. Now, it's been questioned precisely for its incompetence to address inequality and social injustice. (CO-07)

Democracy is the best system so far; but governments are not focusing on understanding social changes, or citizens' changing priorities, or the need to implement new development models. (CO-05)

\section{These crucial problems are interconnected and require collaboration}

In addition to enumerating what they see as the main concerns - and perhaps more importantlythe interviewees remind us that these problems are not standalone issues. To the contrary: problems are often described as complex and interrelated, affecting and being affected by one 
another in a complex web of mutual, intertwined causes and consequences. The interviewees' views therefore corroborate the notion that the most crucial societal problems are typically wicked problems (Rittel \& Webber, 1973; Head \& Alford, 2015), where what is at first perceived as a problem may be in fact a symptom of the combination of other problems.

The interviewees also perceive that the potential solution to these complex problems demands close collaboration among actors from several domains. While they mention government, businesses, and civil society — which represent the three sectors considered by the rebalancing society proposition (Mintzberg, 2015)—some of them also refer to academia (or universities) as a distinct sector:

I believe that there are no social and environmental problems that do not require the collaboration of the three sectors; however, the participation of academia is also inalienable (CO-05).

We believe they see academia as a distinct sector for at least three reasons. First, because universities in Latin America can be categorized as any of the three forms proposed in Mintzberg's (2015) typology: they can be branches of public service, typically administered as a system by the ministry of education (public); they can be for-profit ventures (private); and they can be independent foundations and community institutions run as not-for-profits (plural). Second, the considerable deficit of formal education in the region combined with myriad problems in all areas places universities in the crucial role of the bastions of knowledge needed to solve societal problems. Third, universities in many Latin American countries have historically served as major grounds of political action, often playing a critical role in resisting authoritarian regimes and reinforcing democracies in the region.

The progressive leaders we interviewed also tend to suggest that the articulation of solutions to solve societal problems would require formal public policies defining the necessary engagement of actors from the several domains. This reveals an interesting tension: although the private sector is often recognized as a model for efficient management and an important part of the solution to many problems, there is skepticism that effective change could happen without formal policies. 
However, as the majority of the region is also marked by low trust in governments - which tend to be perceived as self-serving, corrupt, and dysfunctional — it is unclear how these policies should be established. A possible solution might involve mobilization of civil society organizations to press the government to draft public policies that would include articulated action among the public, private, and plural sectors:

When it comes to the inequality agenda, it is unlikely that you will change pointers on this agenda if you do not discuss the role of the state, regulation, taxation, etc. For this, you need to have a framework of organizations that can pressure, dialogue, and negotiate with the state on these regulatory changes; otherwise you cannot make the required changes. (BR-02)

But, as already noted, such an approach may prove impracticable due to the dysfunctionality of political systems, a crucial problem in the region.

\section{Nations matter, but the region shares a common history and faces similar issues}

When commenting on the crucial challenges faced in the region, the interviewees often build arguments contrasting different nations. Pertaining to ideology, on the one hand, Uruguay and Chile are typically mentioned as models of development strongly supported by liberal capitalist ideologies, where businesses are the dominant force to produce economic wealth and development. On the other hand, Venezuela and Cuba are on occasion cited as examples of nations once influenced by socialist ideologies but now dysfunctional in terms of both individual rights and economic development. Interestingly, interviewees often portray Uruguay and Costa Rica as small nations that have achieved particularly high levels of development when compared to other nations in the region:

Costa Rica has the social progress index of a country that is $30 \%$ richer than would be expected. Moreover, it has the highest social progress index in Latin America even though it does nor rank among the five richest in Latin America. That's abnormally positive. (CR-01)

The history of Latin America is that of a crossroads of different cultural traditions that, in very broad strokes, combine European (mostly Iberian) colonization with numerous ancestral Amerindian traditions, the legacy of certain African groups, and, more recently, a geopolitical influence of the US. The region exists therefore as a combination—and under the influence — of 
cultural, ideological, and institutional traditions that are ancestral to the continent but also transposed from Europe, Africa, and the US. The complexity of the region resists however a simplified depiction, in part because the historical construction of each of its nations comprises immigrations of groups from other regions (notably Asia and the Middle East) as well as the exposure to other ideological possibilities (e.g., the communist influence of the former USSR and the current growing ties with China).

Nevertheless, and despite all the diversity and variations existing in each Latin American nation, the interviews reveal some structural similarities across the region. Three common factors emerge as particularly salient: lack of stability, low trust in governments, and disparity in terms of individual opportunities. Such factors manifest to different degrees (with Costa Rica and Uruguay occasionally portrayed as exceptions). Moreover, combined, they have created crucial needs that have contributed to the emergence of strong activist movements (BR-06) and therefore a very active plural sector. Societal problems are both abundant and visible: There are large contingents of the population who are vulnerable and, because they cannot count with the government, the only way out is to take matters into their own hands, thus building creative solutions with limited resources:

It's a very hands-on region with a lot of creativity. We deal with critical problems in these territories, in these peripheries. So, you have a lot of people doing things, creating things, adapting things. When you look at the European context, for example, the nature of the problems they deal with is very different. We have many more critical problems here, which calls for creativity. (BR-02)

Another specific issue that became salient in the interviews is access to land:

The first thing a human being wants after being clothed and fed is to own their home. If we don't resolve the problem of rural land ownership, inequality and conflict are going to remain. (CO-07)

We believe land ownership remains a central concern because it is intrinsically related to the origin of inequalities in the region. Historically, Latin America has been characterized by vast rural properties owned by powerful families who also wielded political power. The industrialization of the region happened mostly without the agrarian reforms that could reduce inequality and, instead, impoverished populations migrated to the outskirts of large cities in search 
of unskilled jobs. While traditional agriculture became modern agribusiness, landowners continued to be overrepresented in political terms. In Brazil, for instance, roughly $40 \%$ of congresspersons have direct or indirect relations with agribusiness (Pereira, 2018). We posit, moreover, that the entrenched inequality of the archaic agrarian structure perpetuated unequal access not only to land ownership but also to education, health care, economic opportunity, and political representation. Unsurprisingly, social movements dedicated to land redistributions that many would perceive as radical and operating at the limits of legality are cited as examples of positive social transformation by some progressive leaders. One notable case is the Movimento dos Trabalhadores Rurais Sem Terra, MST (Landless Rural Workers Movement) in Brazil, which was established in 1984 under Marxist inspiration and is now active in virtually all states in Brazil with an estimated membership of 350,000 families (MST, 2020).

They form a very solid movement. [...] When the MST occupies an area, they set up schools and, based on their partnerships with universities, members have access to higher education. The movement goes well beyond economic survival. They seek economic dignity, which encompasses access to social programs and education. Thus, they ensure that some members become qualified agricultural engineers and lawyers. (BR-06)

Interestingly, MST evolved from its original mission (i.e., to convert underutilized agricultural land into productive settlements) to battling other issues, notably economic inequality, racism, sexism, and media concentration. The movement is also praised for living by the values it preaches and for incorporating mechanisms of self-regulation, such as banishing men who beat women and sanctioning drugs and excessive drinking (BR-06).

Because access to land remains a crucial issue, some of the interviewees question the fundamentals of Latin America's economic systems:

Someone came one day, spotted the land, and said, 'it's mine.' and that is how the inequality began. [...] It's really crazy! Because no one made the land. The land was already here. The Indians, by the way, have a wonderful phrase: 'White man, very funny! He says he owns the land, but he is born, the land already exists. He dies, the land still exists. How can he own the land? It is the land that owns him.' (BR-05)

The notion of arriving at a new place and occupying the land is the very basis of colonization. It corroborates our argument that Latin American nations experience similar problems because they 
share a common history. So, it is no surprise that the very concept of Latin America finds support not in geography but in culture and history: Latin America is not a continent, but a group of geographically close nations in South America, Central America, Caribbean, and North America that share a similar cultural history.

\section{Latin America remains shy in terms of teaching other regions}

We also asked the progressive leaders if Latin America had important lessons to offer. The interviewees were, however, timid to make the case of Latin American solutions being relevant to other global regions. They point to a few large-scale initiatives that proved successful, such as the AIDS reduction campaign in Brazil (BR-01; see also Mintzberg \& Azevedo, 2012) and the Costa Rican actions to reduce inequality and bold decisions to dismantle its armed forces and preserve one third of its territory (CR-07). They are reluctant to advance these solutions as universal ones, however. Instead, they point to specific —albeit diverse — initiatives, such as the public, private, and academic sectors joining forces in Medellin, Colombia, to limit the use of vehicles for a more user-friendly city (CO-08); a set progressive measures taken in Uruguay, such as the decriminalization of abortion, decriminalization of Marijuana, and same-sex marriage (UY-01); the SIFAIS Foundation in Costa Rica that promotes self-improvement and social integration through art education (CR-02); the Municipality Network against Climate Change in Argentina; and a network of companies in the South of Brazil that use swine agroindustry waste to produce biogas (UY-01).

Surprisingly, some even made the case of Latin America being a negative example to the world, in particular for electing bad political leaders and failing to preserve the environment (CO-04). Or, alternatively, the given lesson harkened romanticized representations of Latin America being joyful, despite being submerged in grave problems:

Something that Latin America can teach the rest of the world is joy and the value of celebrating, the value of color, the joy of living. It seems to me that the rest of the world has withered. (CO-06) 


\section{A vision for the region and perspectives on how to solve its most crucial problems}

As our interviewees engage in solving the myriad problems, they also cultivate a vision for Latin America. Despite the diversity of points of view, we came to conclude that they generally envision a good society as a harmonious existence in the social, economic, and environmental spheres, a perspective of progress that goes beyond pursuing economic growth and that instead adopts a sort of triple-bottom-line ambition (Elkington, 1998). Indeed, their vision for the region embraces a view of social harmony where each person contributes to and benefits from the common good, a view of economic harmony where goods and services are produced and shared among all, and a view of environmental harmony where the sustainable use of resources ensures the long-term preservation of nature.

"I had an experience 25 years ago that gave me my very simple definition of "A good society' $[\ldots]$ The best society is the one with the highest percentage of the population who are contributing to and the highest percent benefiting from the happiness, goods, and services being produced. As many as possible producing and everyone benefiting. (CR-06)"

We also spent a substantial part of the interviews discussing how to solve the diverse - and complex - problems faced in the region. Our compilation of their perspectives indicates a convergence towards three major conditions. First, they believe the solutions depend on a certain level of coordination such that the actions of different actors are articulated. Second, they understand that solutions to complex problems depend on individuals taking responsibility for their actions and behaviors, which may require an important shift of mindset. Third, they believe in education — in a broader sense — as crucial to solving these problems.

Their view on the required coordination generally corroborates the rebalancing society proposition:

It is impossible to think about social problems and their impact without taking into account the state, the private sector, beneficiary individuals, or excluding civil society organizations. It is necessary to work in a coordinated way and to identify the role that each has and can play. (UY-03)

Coordinating may entail collaborations of different actors, sometimes with a framework established by the state, such as the Uruguayan initiative of changing its energy matrix by 
attracting the private sector and by allowing "any ordinary citizen to have shares in the new wind farms or the new solar farms" (UY-01). However, when the state fails, there are many other initiatives conducted by organized civil society, corporations, and entrepreneurial individuals, often in collaboration and with little or no participation of the state:

Tomorrow I'm concluding a financial transaction with another system B company: we raise a debenture; the investor will put the money tomorrow; the money will go to fund solar panels and then, part of the resources will go to NGOs to do a job at a public school. So, there is a third sector [organization] here, and two and a half from the second [the private] sector (B-companies) to solve a public problem. (BR-03)

The interviewees also emphasize the importance of the initiatives being developed and executed in close proximity with the terrain. They sometimes make the distinction between the action of NGOs and social entrepreneurs, who have recently emerged as a novel actor to produce social progress in Latin America:

In fact, the best type of social entrepreneur [...] is not an outsider who comes to solve [the problem], but someone who knows [the problem from the] inside, proposing solutions, starting from having his feet immersed in the problem. (UY-03)

There is also a strong claim for a shift of mentality, for people starting to think differently, to understand that the problems are interconnected, and that they should become more responsible for their actions:

We need to communicate to all: 'folks, you need to think differently. Think differently.' and you keep pushing and pushing. [...] people change by changing mentalities, by becoming coherent, and from becoming ashamed of something. (BR-06)

When we become aware that achieving sustainability requires an economic balance, an environmental balance, and a social balance, it makes us pay attention to development issues, such as eradicating hunger. (CO-01)

The interviewees claim that the resolution of complex problems will not be possible unless there is a mindset shift and that one should seek ways of produce such transformation:

Renewing our values depends on a cultural issue, which is how values are transmitted. You do it through education, but also using TV and the entire communication universe we have out there. (BR-06)

Education becomes therefore a fundamental force of change and, indeed, the Latin American progressive leaders we interviewed tend to perceive education — both formal education and 
education in a broader sense - as the basic mechanism to solve problems in the long term. In

particular, they emphasize that education should be the vector to develop the critical thinking that is required to become integral members of society and even to build the values that are required to promote the shift in mindset they expect:

Education includes training in principles and values, such as prevention of corruption and harmful circles generated by the culture of illegality. Likewise, we must learn that legal systems must be simpler systems that generate legal security around behaviors and regulations. (CO-05)

Education is presented as essential mechanism to fight inequality (e.g., Uruguay's “one laptop per child" plan implemented even "in rural places where their parents had never had Internet access" [UY-01]) and as a critical mechanism of inclusion to ensure, for instance, that "people who have a physical, intellectual, or any kind of disability, have access to education" (BR-07). The interviewees emphasize, however, that education has to be nested in the context. The case of UniPeriferias in Brazil is cited as an example of success for bringing education to those who need it without removing them from their communities:

[A well-known educational foundation] selects the brightest in that periphery community and takes them to Harvard. So, they take that person out of their environment and put them in another one. It is then difficult for the person to return to their original environment. So, the idea is, 'we do everything here; we leave our brilliant resources right here to help think about solutions here.' (BR-06)

Thus, they consider education and a transition to new logic as prerequisites to create a large mobilization to face the complex problems in the region:

[There is no social organization] that has the power to create the mobilization we need to make people act in a different way. The government isn't even able to regulate and control what is out there. It all depends on education and on reaching a new logic. Addressing these big challenges is an immense task that, without a doubt, is a task for the entire society. (BR04)

\section{$\underline{\text { Discussion }}$}

In this section, we discuss how the perspectives voiced by the 25 Latin American progressive leaders relate to the rebalancing society proposition. The analysis of the interviews leads us to 
posit that, although the interviewees do not disagree with the underlying principles of Mintzberg's (2015) proposition, the discussion of their experiences as engaged actors suggests that the proposition does not fully account for some of their major concerns.

\section{Rebalancing makes good sense}

During the interviews, the progressive leaders did not spontaneously subscribe to the idea that the problems they face are linked to a lack of balance among public, private, and plural sectors. However, once presented with the central aspects of the rebalancing society proposition, they thought it made good sense and, in particular, they tended to agree that solving complex problems requires the collaboration of players from different sectors.

Moreover, they typically do not reject the specific idea of three sectors, with the third called plural, and some even propose amendments to the model. In particular, as previously mentioned, some suggest that academia is a distinct sector and others call attention to the categories of players that can be in-between sectors, perhaps as hybrids between different logics:

Social entrepreneurs try to tackle the problems from a business model. This is the difference between them and the NGOs. (BR-02)

The Programa Vivenda is a great example of social entrepreneurship. Their guys come and renovate a house in a poor neighborhood for only BRL 5,000 [equivalent to USD 1,000]. And the housing problem is becoming increasingly linked to inequality. (BR-03)

I see the coop as a mix between a NGO and a business. It generates income and is acquainted with the selling of products and services. [...] It is in between two worlds. They may even be better understood as impact enterprises, even if that's not how they see themselves. (BR-02)

The analysis of the interviews reveals nevertheless that the perspectives they voice based on their experiences suggest that the rebalancing society proposition does not fully account for two of their major concerns: the context of low-quality institutions that is typical of Latin America and the need for a more profound mentality shift in the region. 


\section{Is rebalancing society enough when actors and institutions are of low quality?}

While the interviewees contend that the quality of Latin American institutions is low and that people do not trust governments, they rarely think in terms of one sector having too much power or prominence. Instead, they mention good people and bad people, good companies and bad companies, good governments and bad governments, good NGOs and bad NGOs, and so on. This leads us to posit that their concern is not so much with the sector the actors belong to, but its quality. Their concern about the quality of their institutions seems to corroborate the contention that nations may fail because "political and economic institutions interact in causing poverty and prosperity" (Acemoglu \& Robinson, 2012, p. 43).

Put differently, their concern about the institutions and their actors not being able to rise to the challenge precedes their preoccupation with society being out of balance. Thus, actors from the public sector inspire limited expectations because they are perceived as bureaucratic, self-serving, distant from the population, and often corrupt. Private sector actors also raise suspicion because the smaller firms are often focusing on surviving rather than contributing to the society, whereas the larger companies — foreign multinational included — are generally more interested in making a profit and are much less responsible than their corporate social responsibility statements may parlay. Moreover, the civil society actors are often perceived as weak, unable to produce meaningful social transformations, and incapable of articulating their actions with businesses and governments:

Civil society organizations play an important role in social cohesion, but they've limited capacity for social transformation. Most of them are fragmented and institutionally very weak. (CO-06)

Civil society organizations should focus on impact, learn to seduce and communicate, and articulate with both business and the state. (CO-02)

In Mintzberg's views, once a society is balanced, the good actors of each sector will work together to generate the positive outcomes we need:

Balance can encourage feeding off each other and working with each other. There are lots of responsible and concerned businesses. There are governments that are constructive in some of the good things that they are doing. And there is a side of the plural sector that is 
wonderfully positive. The idea is to tap into the positive of each. (Mintzberg, quoted in Azevedo \& Gates, 2019, P. 182)

The progressive leaders suggest, however, that the good actors are perhaps still too few and weak and that a balance among sectors dominated by bad actors, in a context where the institutions are deficient, would possibly fail to yield positive transformation. Therefore, instead of looking at the larger balance of power among sectors, they may be focusing their effort on raising and reinforcing the good actors.

\section{And sometimes an internal rebalancing may also be needed}

Based on their experience, another major concern the interviewees express is the need for what some of them call a shift of mindset. They believe that solving complex problems demands changes in terms of values and, in particular, that individuals should assume their responsibilities, care for the common good, and, once they rise to a position of power, not repeat the same immoral behaviors they criticize vis-à-vis public officers, business people, and civil society leaders.

By their nature, people are attached to power. (BR-05)

We are at a time when everyone in society has to join. NGOs should start to be protagonists and stop being parties. And we must really start to make a revolution like this girl in Europe [Greta Thunberg]. (CO-04)

When those who own the main media outlets are the same as those who control the executive power in the main states of the country and who elect the legislative power etc., it is difficult [to establish a representative democracy.] (BR-05)

In our understanding, they consider that a sort of internal rebalancing is also needed. The progressive leaders we interviewed are not only concerned about the balance among sectors and, as discussed above, a positive transformation to the quality of institutions and actors; they also consider that an internal transformation is necessary. Interestingly, some of the interviewees referred to having transformed their own individual perspective, typically as a wakening-up to crucial problems surrounding them (such as hunger, poverty, and child mortality) and sometimes 
triggered by a difficult event in their lives (such as a long hospitalization period or the passing of a loved one).

I had this insight when I was still in the hospital. I had the decisions of my destiny in my hands, whereas others had no structure, no support at all. And I started to see a reality that I had ignored: families without the basics, children with very grave problems, people who could not afford the most basic of treatments. I realized that I was very privileged and that I should be thankful for what I had. (BR-07)

Once they begin to understand the gravity and complexity of the problems around them, they set about solving them and seek to transform others, thus multiplying the vehicles for positive transformations in society. They seek to help additional good actors to emerge. And they do it by example, by creating organizations that attract new allies for their cause and by permanently reaching out to continue to learn and inspire others.

Their perception that a positive transformation of Latin American societies depends on an internal transformation of the people forming these societies, in a way reflects a famous quote from Mahatma Gandhi: "Be the change that you wish to see in the world."

\section{Looking at the larger picture}

As they work to address the challenges they have chosen to face, the Latin American progressive leaders develop their beliefs about ways of making the changes more effective. The principle of empowerment of individuals emerges often and education, as already discussed, presents as the most important emancipatory tool. Moreover, there is a proneness to move beyond assistencialism to instead promote actions that allow people to be productive and fully integrated into the society:

"The highest form of welfare for the poor is not a handout, it is helping them be productive. If you want to help a poor family, nothing helps more than giving them a good job. Why? Well, it gives them not only the economic means of livelihood but so much more capacities from training, a sense of identity and contribution, belong to community. (CR06)"

The emancipatory transformation of the individuals is therefore a path to allow Latin America to leave behind the sad cultural tradition of being dependent on other regions and 
of seeing itself as inferior. Looking at the larger picture, this is part of an envisaged plan where a broad range of players would converge to a common agenda to promote more systematic changes:

The private sector, the public sector, citizens, the media, and universities should converge so that everyone participates in a common agenda to develop solutions from the roots, changing that narrative and the very understanding of the problems. We should set points of no return towards positive changes. For the moment it is happening individually or between one actor and another; it does not comprise all the actors. So, I think that we need to start to promote more systematic changes. (CO-03)

The solutions come at a more systemic level and all contributing towards the same goal from different roles. (UY-03)

Which leads us to a final reflection: Although devoted to pragmatically and tenaciously addressing the issues they can reach, progressive leaders in Latin America continue to look at the larger picture. A lesson they bring, based on their experience, is that complex problems require more systemic actions that are bold enough to reach to the more pervasive and fundamental issues.

We are used to tackling classic problems in isolation, accordingly to classic themes such as education, sports, health, etc. But when we pursue a more structured arrangement, it breaks that logic. So, I'm talking about problems that go along the lines of democracy, inequality, climate change, just to name a few here. (BR-02)

\section{$\underline{\text { Conclusion }}$}

This study aimed at assessing the experience of engaged actors in Latin America in order to reveal their perspectives about the most pressing problems in the region and whether the solution to these problems could profit from the rebalancing society proposition (Mintzberg, 2015). In countries that share aspects of a common cultural history, even if separated by significant geographical distance and with different sizes and development trajectories, the study identified a high degree of agreement as to what are the most challenging issues the region is facing. These progressive leaders are most concerned about inequality, environmental degradation, and ineffective political systems that fail to fulfill societal expectations. The three problems are multifaceted and have multiple ramifications and effects. Inequality is manifested, among others, in the disparity of 
family income and possession of assets and goods, in the imbalance between capital and labor, and in the restricted access to basic services. Environmental degradation involves issues of local pollution and destruction of ecosystems, as well as the carbon footprint of global value chains and consequent global warming. Dysfunctionality of political systems is also multifaceted and encompasses, among other aspects, unfair elections, corruption, and capture of the state by public officers, ideological manipulation, and political polarization, which lead to social injustice, and erosion of trust in the governments. To complicate matters, these are wicked problems that do not stand on isolation, but rather affect and are affected by one another in a complex web of intertwined causes and consequences.

In this complex picture, the interviewees maintain that the solution to these crucial problems requires the articulated action of different actors; depends on individuals taking responsibility for their actions and behaviors; and necessitates a substantial education effort to support the move to a society that is more egalitarian, long-term oriented, and ready for the challenges. Although they agree with the need for sectors to collaborate, their experiences as engaged actors suggest that the rebalancing society proposition (Mintzberg, 2015) does not fully account for some of their major concerns.

In particular, they appear to be more concerned about the lack of trust and low quality of the actors and institutions integrating the different sectors than about the balance among the sectors.

Moreover, their combined statements also suggest that a positive transformation of the societies in the region depends on an internal transformation of the people, which can produce a change in values and individual empowerment. Finally, pondering the larger picture, they also tend to indicate that complex problems are better addressed by a more systemic and coordinated action bold enough to address the core issues.

We conclude by positing that by interviewing these 25 progressive leaders from Brazil, Colombia, Costa Rica, and Uruguay, we were able to access part of their practical experience and personal reflections, which we contrasted with the rebalancing society proposition (Mintzberg, 2015), 
which was chosen as the theme of the eighth international conference on Strategic Management in Latin America. By opting for a theoretically driven sample, we were searching for well-informed but diverse and original experiences. The interviewees' statements are therefore neither neutral nor free of biases. After all, as one of them said, "what I am talking about relates much more to a segment of the population; it cannot be generalized because I'm living in a bubble of converted and conscious people" (BR-04).

We are nevertheless positively surprised by how the 25 conversations resulted in a composite meta-conversation of a sort that is both coherent and extraordinarily rich. The lessons learned tell tales of different societies in a region that is exuberant in terms of resources and potential but that continues to struggle to find paths to attain its aspiration of a harmonious existence in the social, economic, and environmental spheres. By developing this study—and in accordance with the academic-practitioner philosophy that guides the Strategic Management in Latin America conferences - we trust that what we could learn is useful to academics and practitioners in Latin America and beyond who share the aim of finding ways to better societies. 


\section{$\underline{\text { References }}$}

Acemoglu, D., \& Robinson, J. A. (2012). Why nations fail: The origins of power, prosperity, and poverty. New York: Crown Business.

Azevedo, G. \& Gates, A. (2019). Wake up! The world is out of balance and if you do nothing you are part of the problem: an interview with Henry Mintzberg. Journal of Management Inquiry, 28(2): 180-186.

Bernard, H. R., \& Ryan, G. (1998). Text analysis: Qualitative and quantitative methods. In H. R. Bernard (Ed.), Handbook of methods in cultural anthropology (pp. 595-646). Walnut Creek: Altamira.

Castells, M. (2008). The new public sphere: Global civil society, communication networks, and global governance. The Annals of the American Academy of Political and Social Science, 616(1), 78-93.

Elkington, J. (1998). Cannibals with forks: the triple bottom line of $21^{\text {st }}$ century business. Gabriola Island: New Society Publishers.

FAOStats (2020). Percentage of rural population. Retrieved from: http://www.fao.org/faostat/ Accessed on: 06-June-2020.

Gellner, E. (1995). The importance of being modular. In: J.A. Hall (Ed), Civil society: Theory, history, comparison. (pp. 32-45). Cambridge: Polity Press.

Gioia, D. A., Corley, K. G. \& Hamilton, A. L. (2013). Seeking qualitative rigor in inductive research: notes on the Gioia methodology. Organizational Research Methods, 16(1), 1531.

Global Forest Watch (2020). Dashboard. Retrieved from: https://www.globalforestwatch.org/dashboards/country Access on 01-June-2020.

Gonzalez-Perez, M. A. (2013). Global civil society and international business: a review. Advances in Sustainability and Environmental Justice. 11, 37-63.

Head, B. W., \& Alford, J. (2015). Wicked problems: implications for public policy and management. Administration \& Society, 47(6), 711-739.

Keane, J. (2005). Eleven theses on markets and civil society. Journal of Civil Society, 1(1), 25-35.

Matravers, D. (1998). Introduction. The social contract or principles of political right (pp. IXXV). Kent: Wordsworth Classics.

Milanovic, B. (2019). Capitalism, Alone: The Future of the System that Rules the World. Harvard University Press.

Mintzberg, H. (2009, July-August). Rebuilding companies as communities. Harvard Business Review, 87, 140-143. 
Mintzberg, H. (2015). Rebalancing society: Radical renewal beyond left, right, and center.

Oakland: Berrett-Koehler.

Mintzberg, H., \& Azevedo, G. (2012). Fostering 'Why not?' social initiatives - beyond business and governments. Development in Practice, 22(7): 895-908.

Mintzberg, H., \& Laasch, O. (2020). Mintzberg on (ir)responsible management. In O. Laasch, D. Jamali, R. E. Freeman, \& R. Suddaby (Eds.), The Research Handbook of Responsible Management. Cheltenham: Edward Elgar.

MST (2020). Quem somos [Who we are]. Retrieved from: https://mst.org.br/quem-somos/. Access on 01-Jun-2020.

OECD (2019). Population with tertiary education. Retrieved from:

https://data.oecd.org/eduatt/population-with-tertiary-education.htm Access on 15-June2020.

OECD (2020). PISA results 2018. Retrieved from: https://www.oecd.org/pisa/PIASAresults_ENGLISH.png Access on 06-June-2020.

Patton, M. Q. (2002). Qualitative research \& evaluation methods. (3 ${ }^{\text {rd }}$ ed.). Thousand Oaks: Sage.

Pereira, P. (2018). Agronegócio tem a bancada mais bem organizada [Agribusiness has the best organized congress representation]. Retrieved from: https://infograficos.estadao.com.br/public/politica/eleicoes/2018/os-donos-docongresso/agro/. Access on 02-Jul-2020.

Ritchie, H. \& Roser, M. (2019). Per capita CO2 and greenhouse gas emissions (2017) (in tonnes). Retrieved from: https://ourworldindata.org/co2-and-other-greenhouse-gas-emissions Access on: 06-June-2020.

Rittel, H. W. J., \&Webber, M. M. (1973). Dilemmas in a general theory of planning. Policy Sciences. 4(2): 155-169.

Social Progress Index (2020). Social Progress Index 2019. Retrieved from: https://www.socialprogress.org Access on 06-June-2020.

The Economist Intelligence Unit (2019). EIU Democracy Index 2019 - World Democracy Report. Retrieved from: www.eiu.com Access on 06-June-2020.

Transparency International (2020). Corruption Perception Index (Rank) 2019. Retrieved from: https://www.transparency.org/en/cpi/2019/results Access on 06-June-2020.

UNDP (2020). Human development index (rank). Retrieved from: http://hdr.undp.org/en/data Access on 06-June-2020.

UNStats (2020). SDGs country profile. Retrieved from: https://country-profiles.unstatshub.org Access on 06-June-2020. 
World Bank (2018). World Development Indicators: Deforestation and biodiversity. Retrieved from: http://wdi.worldbank.org/table/3.4. Access on 15-Jun-2020.

World Bank (2019). The World Bank in Uruguay - Overview. Retrieved from:

https://www.worldbank.org/en/country/uruguay/overview. Access on 01-Jun-2020.

World Bank (2020). World Development Indicators database. Retrieved from: https://data.worldbank.org Access on 06-June-2020.

World Inequality Database (2020). Income distribution. Retrieved from: https://wid.world/ Access on: 06-June-2020. 
Tables

Table 1: Interviewed progressive leaders

\begin{tabular}{|c|c|c|c|}
\hline Interviewee & Country & Code & Relevant Positions \\
\hline Beatriz Azeredo & Brazil & BR-01 & Social Sustainability Director, Rede Globo \\
\hline Fábio Deboni & Brazil & BR-02 & Executive Manager, Instituto Sabin \\
\hline João Paulo Pacífico & Brazil & BR-03 & Activist CEO, Grupo Gaia \\
\hline Ricardo Glass & Brazil & BR-04 & $\begin{array}{l}\text { Co-President of the Board, Sistema B Brazil; } \\
\text { Founder, Okena }\end{array}$ \\
\hline Eduardo Moreira & Brazil & BR-05 & Digital influencer, Brasil 247 \\
\hline Katia Maia & Brazil & BR-06 & Executive Director, Oxfam Brazil \\
\hline $\begin{array}{l}\text { Rodrigo Hübner } \\
\text { Mendes }\end{array}$ & Brazil & BR-07 & Director, Instituto Rodrigo Mendes \\
\hline $\begin{array}{l}\text { Alejandro Olaya } \\
\text { Dávila }\end{array}$ & Colombia & $\mathrm{CO}-01$ & $\begin{array}{l}\text { Regional Director, Colombian National Association } \\
\text { of Industrials; Former Director General, Colciencias; } \\
\text { Former University Professor }\end{array}$ \\
\hline $\begin{array}{l}\text { David Escobar } \\
\text { Arango }\end{array}$ & Colombia & $\mathrm{CO}-02$ & $\begin{array}{l}\text { Director, Comfama; Former Planning Director of } \\
\text { Medellin; Former Vice-President, EPM. }\end{array}$ \\
\hline Juliana Gutiérrez Rua & Colombia & $\mathrm{CO}-03$ & $\begin{array}{l}\text { Founder and Director, Low Carbon City; Former } \\
\text { Public Relations Manager, Fundación Éxito }\end{array}$ \\
\hline $\begin{array}{l}\text { Mateo "Jaca" } \\
\text { Jaramillo Cadavid }\end{array}$ & Colombia & $\mathrm{CO}-04$ & Founder, Mattelsa; School Principal, Holss \\
\hline $\begin{array}{l}\text { Verónica De Vivero } \\
\text { Acevedo }\end{array}$ & Colombia & $\mathrm{CO}-05$ & $\begin{array}{l}\text { Former General Secretary of the City of Medellin } \\
\text { VP, Socya }\end{array}$ \\
\hline $\begin{array}{l}\text { Juan Luis Mejía } \\
\text { Arango }\end{array}$ & Colombia & $\mathrm{CO}-06$ & $\begin{array}{l}\text { President, Universidad EAFIT, Former Minister of } \\
\text { Culture of Colombia }\end{array}$ \\
\hline $\begin{array}{l}\text { Gonzalo Restrepo } \\
\text { Arango }\end{array}$ & Colombia & $\mathrm{CO}-07$ & $\begin{array}{l}\text { President of Board of Directors, Fundación Éxito; } \\
\text { Former CEO, Grupo Éxito; representative of business } \\
\text { in the Colombian Peace Process }\end{array}$ \\
\hline $\begin{array}{l}\text { Esteban Agudelo } \\
\text { "Chavo censura" }\end{array}$ & Colombia & $\mathrm{CO}-08$ & Youth activist, entrepreneur, and influencer \\
\hline Alberto Trejos & Costa Rica & CR-01 & $\begin{array}{l}\text { Dean, INCAE Business School; Former Costa Rica's } \\
\text { Ministry of Commerce; Board Member }\end{array}$ \\
\hline Alvaro Salas & Costa Rica & CR-02 & $\begin{array}{l}\text { Former President, Costa Rica's Public Health System } \\
\text { (CCSS) }\end{array}$ \\
\hline Maria Elena Carballo & Costa Rica & CR-03 & $\begin{array}{l}\text { Former Costa Rica's Ministry of Culture; University } \\
\text { Professor }\end{array}$ \\
\hline Margaret Grisby & Costa Rica & CR-04 & $\begin{array}{l}\text { Former CEO, McCann Group; Board Member at } \\
\text { several NGOs }\end{array}$ \\
\hline Guillermo Madriz & Costa Rica & CR-05 & CEO, Centro Cultural Costarricense Norteamericano; \\
\hline
\end{tabular}




\begin{tabular}{|l|l|l|l|} 
& & & Former Executive Director, Music National Center \\
\hline Harry Strachan & Costa Rica & CR-06 & $\begin{array}{l}\text { Former Managing Partner, Bain \& Company; } \\
\text { Founder, Mesoamerica Group }\end{array}$ \\
\hline $\begin{array}{l}\text { Francisco De Paula } \\
\text { Gutierrez }\end{array}$ & Costa Rica & CR-07 & $\begin{array}{l}\text { Former President, Costa Rica's Central Bank; } \\
\text { University Professor; Board Member }\end{array}$ \\
\hline Giselle Della Mea & Uruguay & UY-01 & Founder, 3 Vectores; Board of Directors, Sistema B \\
\hline Guillermo Fork & Uruguay & UY-02 & $\begin{array}{l}\text { Managing Director, Emprendimientos Solidarios; } \\
\text { Coordinator Voluntary Donations }\end{array}$ \\
\hline $\begin{array}{l}\text { Alejandra Rossi } \\
\text { Rodríguez }\end{array}$ & Uruguay & UY-03 & $\begin{array}{l}\text { Executive Director Socialab; former University } \\
\text { Professor }\end{array}$ \\
\hline
\end{tabular}


Table 2: Selected indicators for the studied countries

\begin{tabular}{|c|c|c|c|c|c|}
\hline & Brazil & Colombia & Costa Rica & Uruguay & $\begin{array}{c}\text { Latin America } \\
\text { and the } \\
\text { Caribbean }\end{array}$ \\
\hline $\begin{array}{l}\text { Population } \\
\text { (2018) }\end{array}$ & $209,469,339$ & $49,648,685$ & $4,999,441$ & $3,44,9299$ & $641,357,466$ \\
\hline Independence & $\begin{array}{c}1822 \text { from } \\
\text { Portugal }\end{array}$ & $\begin{array}{l}1810 \text { from } \\
\text { Spain }\end{array}$ & $\begin{array}{l}1821 \text { from } \\
\text { Spain }\end{array}$ & $\begin{array}{c}1825 \text { from } \\
\text { Spain }\end{array}$ & \\
\hline $\begin{array}{c}\text { GDP } \\
\text { composition } \\
\text { by sector } \\
(2018)\end{array}$ & $\begin{array}{c}\text { Agriculture: } \\
4 \% \text {; Industry: } \\
18 \% \text {; } \\
\text { Manufacturing: } \\
\text { 10\%; Service, } \\
\text { value added: } \\
63 \%\end{array}$ & $\begin{array}{c}\text { Agriculture: } \\
6 \% \text {; Industry: } \\
27 \% \text {; } \\
\text { Manufacturing: } \\
\text { 11\%; Service, } \\
\text { value added: } \\
57.7 \%\end{array}$ & $\begin{array}{c}\text { Agriculture: } \\
5 \% \text {; Industry: } \\
19 \% ; \\
\text { Manufacturing: } \\
\text { 12\%; Service, } \\
\text { value added: } \\
68.4 \%\end{array}$ & $\begin{array}{c}\text { Agriculture: } \\
6 \% \text {; Industry: } \\
24 \% \text {; } \\
\text { Manufacturing: } \\
\text { 12\%; Service, } \\
\text { value added: } \\
60.8 \%\end{array}$ & \\
\hline $\begin{array}{c}\text { GDP per } \\
\text { capita (USD) } \\
(2018)\end{array}$ & 14,951 & 14,834 & 19,762 & 22,116 & 16,529 \\
\hline
\end{tabular}

Data sources: OECD (2020), World Bank (2020). 
Table 3: Inequality indicators in the four countries

\begin{tabular}{|l|c|c|c|c|}
\hline & Brazil & Colombia & Costa Rica & Uruguay \\
\hline GINI index (2018) & 53.9 & 50.4 & 48.0 & 39.7 \\
\hline $\begin{array}{l}\text { Unemployment (\% of all labor force) } \\
(2019)\end{array}$ & 11.9 & 9.1 & 11.5 & 8.3 \\
\hline Last land reform & 1964 & 1936 & 1962 & 1815 \\
\hline $\begin{array}{l}\text { Percentage of rural population (\% of total } \\
\text { population) (2018) }\end{array}$ & $13.4 \%$ & $19.2 \%$ & $20.5 \%$ & $4.7 \%$ \\
\hline $\begin{array}{l}\text { Year of abolition of slavery } \\
\text { Top 1\% of national income share }\end{array}$ & $28.3(2015)$ & $20.4(2010)$ & N/A & $14(2012)$ \\
\hline $\begin{array}{l}\text { Percentage of the urban population living } \\
\text { in slums (2016) }\end{array}$ & 16.3 & 28.1 & 3.9 & N/A \\
\hline $\begin{array}{l}\text { Percentage of women between 20 to 24 } \\
\text { years of age reported having been married } \\
\text { before their eighteenth birthday }\end{array}$ & $26.2(2006)$ & $23.4(2015)$ & $21.2(2011)$ & $24.6(2013)$ \\
\hline $\begin{array}{l}\text { Percentage of population with tertiary } \\
\text { education (25 to 34-year-olds) }\end{array}$ & $19.7(2017)$ & $29(2018)$ & $27.8(2018)$ & N/A \\
\hline
\end{tabular}

Data sources: FAO Stats (2020), OECD (2019, 2020), World Bank (2020), UNDP (2020), World Inequality database (2020), UNStats (2020). 
Table 4: Indicators of environmental degradation in the four countries

\begin{tabular}{|c|c|c|c|c|}
\hline & Brazil & Colombia & Costa Rica & Uruguay \\
\hline Loss of tree cover (2001-2019) & $56.5 \mathrm{Mha}$ & $4.34 \mathrm{Mha}$ & $0.24 \mathrm{Mha}$ & $0.36 \mathrm{Mha}$ \\
\hline $\begin{array}{c}\text { Percentage decrease in tree } \\
\text { cover (2001-2019) }\end{array}$ & $11 \%$ & $5.3 \%$ & $6.3 \%$ & $21 \%$ \\
\hline $\begin{array}{c}\text { Percentage of total area of } \\
\text { humid primary forest lost } \\
\text { (2002-2019). }\end{array}$ & 6.7 & 2.5 & 1.7 & N/A \\
\hline $\begin{array}{c}\text { Threatened species of } \\
\text { mammals, birds, and fishes } \\
(2018)\end{array}$ & 348 & 30 & 102 & 382 \\
\hline $\begin{array}{c}\text { Per capita CO2 and greenhouse } \\
\text { gas emissions (2017) (tons) }\end{array}$ & 2.27 & 1.66 & 1.77 & \\
\hline
\end{tabular}

Data sources: Global Forest Watch (2020), World Bank (2018), Richi \& Rosser (2019) 
Table 5: Indicators related to the dysfunctionality of political systems in the four countries

\begin{tabular}{|c|c|c|c|c|}
\hline & Brazil & Colombia & Costa Rica & Uruguay \\
\hline Last dictatorship & $\begin{array}{c}1985 \text { (João Baptista } \\
\text { de Oliveira } \\
\text { Figueiredo) }\end{array}$ & $\begin{array}{c}1957 \text { (Gustavo Rojas } \\
\text { Pinillas) }\end{array}$ & $\begin{array}{l}1919 \text { (Federico } \\
\text { Tinoco Granados) }\end{array}$ & $\begin{array}{c}1985 \text { (Gregorio } \\
\text { Conrado } \\
\text { Álvarez) }\end{array}$ \\
\hline $\begin{array}{c}\text { Social Progress Index, } \\
2019 \\
\text { (out of 149) }\end{array}$ & 49 & 60 & 34 & 41 \\
\hline $\begin{array}{l}\text { EIU Democracy } \\
\text { Index, } 2019\end{array}$ & $\begin{array}{c}6.86 / 10.0 \\
\text { "Flawed democracy" }\end{array}$ & $\begin{array}{c}7.13 / 10.0 \\
\text { "Flawed democracy" }\end{array}$ & $\begin{array}{c}8.13 / 10.0 \\
\text { "Full democracy" }\end{array}$ & $\begin{array}{c}8.38 / 10.0 \\
\text { "Full democracy" }\end{array}$ \\
\hline $\begin{array}{l}\text { Human Development } \\
\text { Index Ranking, } 2018 \\
\text { (out of 189) }\end{array}$ & 79 & 79 & 68 & 57 \\
\hline $\begin{array}{l}\text { Corruption Perception } \\
\text { Index, } 2019 \\
\text { (out of 198) }\end{array}$ & 106 & 96 & 44 & 21 \\
\hline
\end{tabular}

Data source: Transparency International (2020), The Economist Intelligence Unit (2019), Social Progress Index (2020), UNDP (2020). 